\title{
Impact of Communication and Information on the Internal Control Environment in Palestinian Universities
}

\author{
Samy S. Abu Naser ${ }^{1 *}$, Mazen J. Al Shobaki ${ }^{2}$ and Tarek M. Ammar ${ }^{3}$ \\ Department of Information Technology, Faculty of Engineering and Information \\ Technology, Al-Azhar University, Gaza, Palestine \\ 1abunaser@alazhar.edu.ps, ${ }^{2}$ mazen.alshobaki@gmail.com, \\ ${ }^{3}$ Tarek.ammar1979@gmail.com
}

\begin{abstract}
The study aims to identify the impact of information and communication on the internal control environment, empirical study on the Palestinian universities in the Gaza Strip, where the researchers dealt with five universities to see the impact of communication and information on internal control environment in these universities. The researchers adopted in his study descriptive and analytical approach. The study population consists of employees with administrative functions, either administrative or academic, with the exception of those in senior management or the University Council. The study population was (392) employees. A stratified random sample was chosen. (197) questionnaires were distributed and the number of questionnaires recovered was (160) questionnaires with recovery rate of $(81.2 \%)$, the researchers used a questionnaire to collect the data. The collected data were processed using (SPSS) to get the results.

The study found the following results: the existence of shortcomings in the administrative communication in generally within the universities and therefore this shortcoming will reflect on the entire regulatory process especially that the communication process represents a significant part of everyday business. There exist a significant relationship between information and communication from one side and the internal control environment from the other side. The lack of significant difference between the responses of the respondents attributed to the variable (gender, age, and years of service). The existence of a fundamental difference between the responses of the respondents attributed to the variable (university, educational qualification, the administrative level).

The study found a set of recommendations including: the importance of updating systems and instructions of control periodically and parallel with the wheel of technology and scientific progresses. The emphasis on administrative leaders to be a positive role model and set an example for employees in all business functions. Benefit from regional and international experiences in the application of control standards commensurate with the administrative system of the institution. The need to hold training courses for employees in the universities. Raise awareness of the importance of the control process and its benefits.
\end{abstract}

Keywords: Information and communication, Internal Control Environment, Palestinian higher educational institutions, Palestinian universities, Gaza Strip

\section{Introduction}

Communication is essential to effective decision-making. It is the mean of which information for the decisions is transmitted through it, which is the basis for the implementation of decisions (Al-Farra, 2008). Since the communication is a practical and dynamic processes in any regular institution, interfere in all other administrative processes, and facilitate its work which constitute a fundamental necessity means for all individuals, in all political, social, cultural, educational organizations, and others. The information is necessary for the unit for the implementation of the control responsibilities in order to achieve the goals, management receives, generate, use appropriate, and quality

Received (March 7, 2017), Review Result (November 6, 2017), Accepted (November 12, 2017) 
of information from internal and external sources to support the work of all control components.

The control is one of the most important topics that concern of accountants, financers and economists also of interest to lawyers and administrators as it works to protect the money and calls for the use of the best available economic resources to achieve growth, stability, and to ensure the achievement of financial activity of its objectives (Badawi, 2011). Control has witnessed continuous development in its concepts, starting to look at their importance in protecting assets from theft, misuse and make sure the information is correct and detect irregularities and wastage, passing through the broader concept, which includes raising the operational efficiency and commitment to implement laws and policies in place, as well as the credibility of the financial reporting and improve the quality of financial reporting and reduce audit and lost time in addition to reduce costs and minimize losses.

\section{Study Problem}

Control is among the main functions of the success of the administrative process which is an important job that overlap with all other administrative functions. It is function because it is concerned with maintaining the quality of the business.

Lack of owning an enterprise control system under the Technology Information and communication where the growing role of technology in all the activities has seen all the work development sectors and improve the quality of services offered through the maximum benefit from the fruits of information technology and new applications that have efficient, speed, and a high level of performance, but the control is still in the narrow limits that has not seen a major development in the methods and procedures because of the complex routine procedures under the usage manual and the lack of a mechanism which operates in controlling the work and efficiency of the staff.

In terms of strengthening the principle of preventive control predicted errors before they can occur, work to reduce costs, time-bound to the process of correction, and the Higher Education Law No. (11) for the year 1998, which lacked the list of executive describes the responsibility of universities towards the ministry as well as the responsibility of the ministry to the higher educational institutions of Palestinian national authority, which weakens the system of accountability at universities. The law is limited to the jurisdiction of the ministry to issue decisions and regulations, which form a lack of legislation regulating the work of higher education institutions in the Palestinian National Authority. There are no Blogs for staff of the Palestinian universities in the Gaza Strip despite the fact that some universities include bulletins, set of standards, and values to be observed during the performance of employees to their functions and duties.

\section{Study Question}

Q1: Is there an effect of the use of information and communication on the internal control environment in the Palestinian universities - Gaza Strip?

\section{Study Hypotheses}

H1: There is no statistically significant effect between the communication and information and the internal control environment in the Palestinian universities in Gaza Strip.

H2: No statistically significant differences in the views of the sample study on the application of control, depending on the demographic variables (gender, age, university, educational qualification, the administrative level, and years of experience). 


\section{Study Objectives}

- Explain the importance of communication and information in the Palestinian universities in the Gaza Strip.

- Study internal control environment in the Palestinian universities in Gaza Strip environment.

- Disclosure of the impact of information and communication in the internal control environment within the Palestinian universities in Gaza Strip.

- Make proposals contributing to the increased application of the concept of control in the Palestinian universities in Gaza Strip.

- Make recommendations to increase the ability of communication and information on the internal control environment in the Palestinian universities in Gaza Strip.

- Identify the concepts and applications of controls, and its importance for universities.

- Detect whether there are significant differences between the mean scores of estimation working in universities around the axes according to the study (gender, age, university, educational qualification, the administrative level, and years of experience).

\section{Study Importance}

The importance of the study is in the importance of the subject matter, they are of interest to researchers and scholars, as there is an urgent need to push for a control system according to a scientific, practical, and clear methodology. The importance of study can be highlighted through:

- This study derives its importance from the subject matter that is characterized by modernity, excellence, scientific and practical alike.

- This provides search data to help researchers and scholars in this field.

- This study is highlighting the area of control within organizations.

- This study derives its practical importance of the importance of the sector, which conducted the study and vitality of this sector, in addition to the significant growth that has occurred on this sector.

- Clarify the concepts and practices of Arab universities were probably more vulnerable than ever and even more in need of advanced universities themselves to administrative concepts and methods of scientific rational and advanced technological tools in order to achieve the desired development through institutional development.

- Drew the attention of Palestinian university management to the importance of control practice because of its role in the development of the institutional performance and raise the profile of the university at the local and regional level.

- Provide scientific and practical recommendations for Palestinian universities to help achieve control. 


\section{Study Limits and Scope}

Place Limitations: the study was conducted on the Palestinian universities in Gaza Strip, two of which are public universities, two private universities and one governmental university.

Human Limitations: The study was conducted on the administrative and academic staff with administrative post in Palestinian universities in Gaza Strip.

Time Limitations: the study was conducted, preliminary data was collected, and statistical analysis was performed during the year (2017).

Subject (Academic) limitations: the study was limited to the communication and information and its impact on internal control environment - Empirical Study on the Palestinian universities in Gaza Strip.

\section{Study Methodology}

The researchers used the descriptive and analytical approach which commensurate with the nature of the study.

\subsection{Study Content}

Research is divided into two frameworks: theoretical and applied frameworks. Theoretical framework includes study variables of communication, information, and internal control environment. The applied framework is a questionnaire that addresses employees in the universities of Gaza Strip. The collected information is analyzed to produce useful results that can be applied.

\section{Theoretical Framework}

\section{First- Communication and information:}

Communication is the continuous process of planning, provisioning, participating, and to obtaining the necessary information. Communication in the administrative filed means: a set of methods, arrangements, and means to ensure the production, delivery, and the use of necessary data for management to become in a position to make sound decisions in the right direction and timing (Tabash, 2008).

American Society for Training defines process of communication as: the process of exchange of ideas and information in order to find a common understanding and trust between the human elements in the organization (Abu-Rahma, 2012).

Others defined it as the process of communicating and receiving the information between two parties (sender and receiver), and this means the interaction between them about information, opinion, direction, or behavior (Tabash, 2008).

Administrative communications are divided to: internal and external communications; internal communication is the means by which information is distributed through the ups and downs and inside institution within the same unit and help people to get clear information from senior management, which oversees the responsibilities that must be taken seriously. The external communications shall be a two-way they are able to connect and communicate by giving information to outside parties and get it from them as needed (COSO Frame Work, 2011).

\section{Importance of the process of administrative communications}

The importance of communication as a process of administrative vital and essential to each organization in the following points (Abu-Salmiya, 2012): 
- Administrative communication helps to achieve and accomplish the goals of any institution, depending on the extent of the administrative efficiency of the existing communication and techniques used.

- It leads to the exercise of power and organize the work of institutions.

- The connection is considered a good way to unite the various efforts in the enterprise and work to bring about a change in the behavior of workers, and strengthening the relationship between them and the institution.

- Contact plays a prominent role in the establishment of trust, respect and mutual understanding, and closer ties and links between the institution and its clients, whether they are individuals or institutions (Tabash, 2008).

- Educate individuals in the community to the objectives of the organization and its activities, which helps good administrative communication in strengthening the relationship between the organization and those individuals working in, and introduce them to the economic and social conditions in which the organization operates within its framework.

- Contribute to facilitate the work of control.

- Communication is generally considered with its various forms has a high degree of importance in the organization, studies and research indicated that communication represents approximately $75 \%$ of the activity in the organization distributed over all its forms, formal and informal.

\section{The elements of effective communication}

In order for communication to be effective; between its components (Abu-Rahma, 2012), which can be summarized as follows:

- Listening: one of the elements of effective communication; which offers the opportunity to get to know the truth of what he wants subordinates, and this in turn increases the effectiveness of management decisions.

- Explanation: Effective communication is required from the leader to clarify his thoughts and give full explanation in order to be influential in personnel.

- Question and Discussion: Effective leader determines the goal of communication and gives the opportunity for his subordinates to ask, inquire, and encourage them to remove fear from criticism.

- Rating: Effective leader is the one who is always standing on the reaction to his message, depending on his assessment of his communication on feedback from employees, leading to motivate them and improve performance.

- Response: It is the leader's ability to observe the communication requirements of the position in the face of his behavior, taking into account the regulatory barriers, and the percentage that could disrupt communications with the understanding of the situation surrounding circumstances.

The researchers add that there is a need to document the communication process, such as: the timing of the transmission, the timing of receipt, text or the content of the message.

\section{The importance of effective communication}

The importance of communication for managers and employees in the Palestinian universities stems from several aspects including (Al-Masri, 2015): 
- The ability to accomplish goals depends on the efficiency of communications highlighted by the employee in his work. Studies have shown that the success achieved by the human in his work $85 \%$ depends on the versatility of communication and only $15 \%$ depends on practical skills or specialized profession.

- The communication process is a major part of everyday business, some experts estimated that they consume between $75-95 \%$ of staff time.

- They are useful for the transfer of information, data, statistics, and concepts through various channels, including contributing to the management decisions and achieve the organization's success and development.

- It is essential in guiding and changing individual and collective behavior of employees.

- Contribute to the transfer of concepts, ideas, and thoughts through official channels to create cohesion among the organization and unite their efforts so that they can achieve their goals.

- Communication is a meaningful way to ensure the joint interaction of different organization activities.

\section{The information}

It defines information as: a set of data collected and prepared in a way that made them useable for the recipient or its user. It is accounting for output in the information system and have an impact in the various decision-making (Yassin and Al Zoghbi, 2002). The information: is a database that has been treated in a manner provided by the meaning, to use and benefit from them in the decision-making (COBIT, 2013).

\section{Second- internal control}

The concept of control is a management tool that can be relied upon to regulate the conduct of matters movement in the organization, according to the tracks that define for it to achieve the desired goals and to ensure this, the concept of internal control emerged in the institutions that cares mainly about the extent of the commitment of the processes involved in the implementation mechanism, judging of faith in the modern management of the importance of the services performed by the functions of the internal control. It was accorded a great importance by the organizations (Abbas, 2009).

The construction of the internal control systems is essential for the purpose of achieving specific control objectives to management which are operational efficiency, reliability of financial reporting activities, and compliance with laws and regulations (Alsaboa, 2011). The system of internal control is a set of processes, functions, activities, subsystems, and the people who came together in order to ensure the achievement of the purposes and objectives (Dahmash and Abu zer, 2005).

\section{Elements of internal control}

(Al-Azmi, 2012) refers that effective internal control process must contain the following elements (ingredients):

- Clear and logical plan for regulatory functions that represent the obvious outlines to the authorities and responsibilities of each organizational unit and its staff, with the need to separate the different functions (authorization, financing, operation and registration and retention of assets and money). 
- Adequate financial system for the operations and activities to identify financial relations with clear and reasonable procedures to record the results of these transactions and activities.

- The existence of sound administrative practices which enable each administrative unit and employees in it to perform tasks, functions and duties effectively.

- The existence of clear criteria for quality performance of the work of the staff in different levels.

- Having the right person in the right place, which should be enjoyed with the ability, competence, experience, and adequate training to do the work entrusted to him satisfactorily.

- The existence of a good internal audit system which is based on a professional basis, effective, and independent audits for the position.

Internal control systems are considered as a safety valve to ensure that the economic unit work is in accordance with the laws, policies and procedures adopted to provide products and services with high quality and high degree of efficiency, effectiveness and asset protection from abuse or use by adopting information systems (accounting and administrative) from which to provide financial and administrative information that is correct, certified and reliable (Alkheir, 2013).

\section{Previous Studies}

The study of (Al-Qahtani, 2015) aimed to recognize the reality of management control within the sports clubs. It followed the descriptive method survey manner which included 334 members representing all the members of the boards of directors, managers and administrators of 22 sports clubs. The most important findings of study was that the activation of the internal control methods applied in achieving sports clubs internal control systems got a medium degree of approval for each one. The creation of specialized units to measure the level of achievement for clubs employees and the development of regulatory standards for clubs on a regular basis, and the establishment of a special department to follow up the decisions of the Board with the use of modern techniques in the evaluation of the club level performance, and strengthening the specialized management of internal administrative control sports clubs.

Study of (Awad, 2012), which aimed to assess the effectiveness of the internal control system in light of the accounting information electronic systems in Islamic banks operating in Gaza Strip, and that three banks totaling in light of technological advances and the ability of systems to provide relevant and appropriate information to decision makers in a timely manner. The study found the need to comply with administrative and accounting policies set by senior management, and the need for a separate departments for electronic data processing in the organizational structure and the need for the existence of the assets and files and protect safety regulations, and impose severe penalties when the discovery of irregularities that indicate dishonesty.

The study of (Badawi, 2011) which aimed to identify the impact of the internal control elements according to the COSO framework to achieve the control objectives in the civil organizations in the Gaza Strip, and then to identify the extent of the evolution of building the internal control systems in the structures of these organizations. The study has shown a great interest by the civil society organizations operating in Gaza Strip with internal control systems. It turns out that the NGOs consider positively with varying degrees the importance of internal control elements in achieving control objectives, achieving effectiveness, operational efficiency, credibility of the financial reporting activities, promoting compliance with laws and regulations. The internal control environment variable was the most significant and has the highest impact in achieving those goals, 
followed by risk assessment variable, regulatory activities variable, information and communication variable, and follow-up variable is ranked last but in general there is a significant effect of the control elements combined to achieve control objectives.

Study of (Rong-Ruey Duh et al, 2010), which aimed to look at the relationship between the internal control in accordance with the standard (COSO), operational efficiency of the universities, contrary to business organizations, where shareholders are the key stakeholders class and profitability is the primary goal, universities that serve the community through the provision of education and scientific research, and it has a group scattered from stakeholders, relying on the idea of intensive category of stakeholders, for example, (shareholders) to monitor the performance becomes less vain, because the internal controls at the universities (internal control) is not less important than the business organizations. At the end of (2005) 160 questionnaire were distributed to 55 public universities, especially in Taiwan 105, with support from the Ministry of Education, 121 were recovered with an average of $75.63 \%$ in response, got rid of 7 questionnaires because they were incomplete, and excluded 15 due to insufficient data, the left 99 questionnaire, 35 of which government and 69 private. The results indicated that the implementation of internal controls in the private universities has a positive and significant relationship between the internal control and efficiency related to teaching, at a time when the link is significant in the case of public universities with efficiency.

Study of (Dherb, 2010), which aimed to look at the modern concepts to evaluate internal control systems and establish the general framework of internal control systems in accordance with the model (COSO), define the key rules to this concept, the types of controls within the internal control system, offer a practical model for self-assessment of control risk, through which to identify and diagnose the risk, size, type and degree of impact, whether internal or external risks faced by each institution in various activities and the diversity of its business, through its exercise of its activity and for the sustainability of survival to be then put the officer oversight, the correct procedures, treatments, and appropriate in accordance with the available resources of the institution and to ensure the achievement of its objectives and its survival. It concluded a set of conclusions the most important one is the failure of most of the institutions working in the public sector to estimate and measure the risks to the institution, and therefore does not adopt the Self model for risk assessment. Whenever there was a high cooperation and coordination between the senior management of the institution and between cadres of regulatory and accounting regarding diagnosis of risks and setting controls the greater the effectiveness of self-assessment of the risks.

The study of (Dahmash, and Abu-Zer, 2005), which aimed to stand on the importance of controls and internal audit, especially in the IT environment because the modern world is characterized by a high degree of complexity and interdependency specially the change in the economic, financial, and accounting matters auditing, as a result of rapid and successive technological developments methods and tools of production, the methods and means of communication, information systems and its transfer, as well as the emergence of new organizational forms, multinational companies, which increased competition and gravity necessitating to take quick and effective decisions, so that the organization can continue to compete and maintain advantages in the market, which requires the availability of current and accurate information to assist in making rational economic decisions. This requires building an information system designed to identify the type and volume of data, and how it was collected, processed, and analyzed, also the presence of effective control, and auditing their output when the raw data is converted into useful and reliable information for decision-making and performance evaluation. 


\section{Study Methodology}

In order to achieve the objectives of the study, the researchers used the descriptive and analytical approach through which the phenomenon, the subject of research, was described, its data was analyzed, the relationship between its components, the views about it, the processes it include, and its effects. The necessary primary data was collected using stratified random sample. The calculated sample size was (160) employees.

Population and study sample: The study population consists of all administrative employees and academic employees with administrative duties. The senior management or the University Council was excluded. The targeted employees are the ones who have supervising positions with numerous administrative titles depending on the type of university. The researchers has an inventory of (392) position names.

The selection of this sample was because it easy to reach them and they are aware of what the concept of internal control. It is evaluated by top level management in addition to the ones they are evaluating those who are under their command and they are required to provide the necessary information to those that under their command.

The following table shows the administrative titles according to the universities and the number of members of the community, divided into universities:

Table 1. Census of Employees in the Universities

\begin{tabular}{|l|c|}
\hline \multicolumn{1}{|c|}{ University } & Total \\
\hline Palestine university & 42 \\
\hline Islamic university & 127 \\
\hline Al-Azhar university & 95 \\
\hline Al-Aqsa university & 113 \\
\hline Gaza university & 15 \\
\hline \multicolumn{1}{|c|}{ Total } & $\mathbf{3 9 2}$ \\
\hline
\end{tabular}

Source: administrative affairs at universities in question, 2017.

\section{Results of Statistical Analysis}

The study presents the analysis of data and hypotheses test, by answering the study questions and review of the most important results of the questionnaire, which was reached through analysis of the paragraphs, stand on the demographic variables. So statistical treatment of the data collected from the questionnaire was conducted. The Statistical Package of Social Studies (SPSS) was used get the study results that were presented and analyzed.

\section{The following statistical tests were used:}

- Frequencies \& Percentages: to describe the study sample.

- SMA and relative SMA.

- Cronbach's Alpha Test to determine the stability of the paragraphs of the questionnaire.

- Kolmogorov-Smirnov Test to examine whether the data follow a normal distribution or not.

- Pearson Correlation Coefficient test to measure the degree of correlation: This test is based on the study of the relationship between two variables. Researchers have used it to calculate the internal consistency and structural validity of the questionnaire as well as to study the relationship between the fields.

- T-test in the case of one sample to see whether the average of the response has reached 5.5, more, or less. The researchers used it to make sure the average significance of each paragraph of the questionnaire. It has also been used Mann- 
Whitney Test for the same purpose in the case of data that do not meet parametric condition.

- Kruskal-Wallis Test was used.

Testing the reliability and validity of the tool

First: Validity of the study tool

Validity of the study tool (Questionnaire) is to measure what the questionnaire was developed to measure. The researchers verified the validity of the questionnaire in two ways:

\section{Internal Validity}

Internal validity means: the consistency of each paragraph of the questionnaire with the axis that this paragraph belongs to. It is calculated by finding correlation coefficients between each paragraph of the fields of the questionnaire, and the total score of the field itself.

Table 2. The Correlation Coefficient Between Each Paragraph and Total Score of Axis

\begin{tabular}{|l|c|c|}
\hline \multicolumn{1}{|c|}{ Paragraph } & $\begin{array}{c}\text { Pearson } \\
\text { Correlation }\end{array}$ & Sig. \\
\hline $\begin{array}{l}\text { Internal control system provides a description and functionally defines the } \\
\text { powers, duties, the degree of knowledge, and skill to perform the work } \\
\text { efficiently and effectively in the university }\end{array}$ & $0.869^{* *}$ & 0.000 \\
\hline $\begin{array}{l}\text { Internal control check compliance with laws, regulations, instructions, policies } \\
\text { and regulations that encourage employees at the university to adhere to moral } \\
\text { values in the performance of the tasks assigned to them. }\end{array}$ & $0.859^{* *}$ & 0.000 \\
\hline $\begin{array}{l}\text { Internal controls contribute to the commitment that each employee works } \\
\text { under the direct supervision responsibly. }\end{array}$ & $0.806^{* *}$ & 0.000 \\
\hline $\begin{array}{l}\text { University demonstrates its commitment to attract, develop distinctive and } \\
\text { qualifying elements in line with targets. }\end{array}$ & $0.748^{* *}$ & 0.000 \\
\hline $\begin{array}{l}\text { Impose strict and deterrent penalties by the management responsible for the } \\
\text { university when the discovery of irregularities indicates manipulation of } \\
\text { business performance. }\end{array}$ & $0.512^{* *}$ & 0.000 \\
\hline$* *$ Correlation is significant at the 0.01 level (2-tailed). & \\
\hline
\end{tabular}

Table 3. Correlation Coefficient between each Paragraph of Communications and Information Axis, and the Total Score of the Axis

\begin{tabular}{|l|c|c|}
\hline \multicolumn{1}{|c|}{ Paragraph } & $\begin{array}{c}\text { Pearson } \\
\text { Correlation }\end{array}$ & Sig. \\
\hline $\begin{array}{l}\text { Internal controls provide information to individuals in time to enable } \\
\text { them to pursue their responsibilities efficiently and effectively. }\end{array}$ & $.898^{* *}$ & 0.000 \\
\hline $\begin{array}{l}\text { Internal control provides efficient and effective communication } \\
\text { channels for the process of transferring that data and information }\end{array}$ & $.907^{* *}$ & 0.000 \\
\hline $\begin{array}{l}\text { Management provides the best administrative communication } \\
\text { methods. }\end{array}$ & $.858^{* *}$ & 0.000 \\
\hline $\begin{array}{l}\text { Internal control provides administrative information for decision } \\
\text { making }\end{array}$ & $.874^{* *}$ & 0.000 \\
\hline$* *$ Correlation is significant at the 0.01 level (2-tailed). & \\
\hline
\end{tabular}

\section{Structural Validity}

A structural Validity mean the extent to which the goals of the tool wants to reach are validated, and shows the relevance of each field of study with total core of the paragraphs of the questionnaire (Al-Gergawi, 2010). 
Table 4. The Correlation Coefficient between each Degree of Questionnaire Axes, and the Total Degree of the Axis

\begin{tabular}{|l|c|c|}
\hline \multicolumn{1}{|c|}{ Pivot } & Pearson Correlation & Sig. \\
\hline Internal Environment & $.912^{* *}$ & 0.000 \\
\hline Information \& Communication & $.926^{* *}$ & 0.000 \\
\hline$* *$ Correlation is significant at the 0.01 level (2-tailed). & \\
\hline
\end{tabular}

Table 4 shows the correlation between the degree of each axis of the questionnaire and the total degree of the axis, as it shows that the correlation function at the significant level of $(0.05 \geq \alpha)$. This indicates soundness of the structural validity.

\section{Second: the Reliability of the study tool}

Tool (Reliability) means: The questionnaire gives the same result if it had been redistributed again under the same circumstances and conditions, or in other words, the stability of the results of the questionnaire do not change significantly if it were redistributed to the study sample several times during certain time periods (Al -Gergawi, 2010).

\section{Table 5. Cronbach's Alpha Testing Results which Measure the Stability of the Overall Questionnaire}

\begin{tabular}{|l|c|}
\hline \multicolumn{1}{|c|}{ Paragraph } & $\begin{array}{c}\text { Cronbach's Alpha if } \\
\text { Item Deleted }\end{array}$ \\
\hline $\begin{array}{l}\text { Internal control system provides a description and functionally defines the } \\
\text { powers, duties, the degree of knowledge, and skill to perform the work } \\
\text { efficiently and effectively in the university }\end{array}$ & .934 \\
\hline $\begin{array}{l}\text { Internal control check compliance with laws, regulations, instructions, } \\
\text { policies and regulations that encourage employees at the university to adhere } \\
\text { to moral values in the performance of the tasks assigned to them. }\end{array}$ & .934 \\
\hline $\begin{array}{l}\text { Internal controls contribute to the commitment that each employee works } \\
\text { under the direct supervision responsibly. }\end{array}$ & .934 \\
\hline $\begin{array}{l}\text { University demonstrates its commitment to attract, develop distinctive and } \\
\text { qualifying elements in line with targets. }\end{array}$ & .934 \\
\hline $\begin{array}{l}\text { Impose strict and deterrent penalties by the management responsible for the } \\
\text { university when the discovery of irregularities indicates manipulation of } \\
\text { business performance. }\end{array}$ & .939 \\
\hline $\begin{array}{l}\text { Internal controls provide information to individuals in time to enable them to } \\
\text { pursue their responsibilities efficiently and effectively. }\end{array}$ & .930 \\
\hline $\begin{array}{l}\text { Internal control provides efficient and effective communication channels to } \\
\text { the process of the transfer of information and data. }\end{array}$ & .931 \\
\hline Management provides the best administrative communication methods. & .931 \\
\hline $\begin{array}{l}\text { Internal controls provide the necessary administrative information for the } \\
\text { process of decision-making. }\end{array}$ & .926 \\
\hline
\end{tabular}

The results indicated by (SPSS) program that the Cronbach's alpha coefficient was 0.938 , which indicates a high reliability as the accepted ratio between statisticians is 0.60 .

Values under the column (Cronbach's Alpha if Item Deleted) in table 2 if any paragraph is deleted would not lead to an increased in the stability of study tool (all values less than (0.939), indicating that the paragraphs are appropriate in the tool. 


\section{Analysis of Sample Properties}

\section{The first analysis of demographic data}

Using the analysis program (SPSS) to analyze particular demographic variables of data (gender, age, university, degree, job classification, number of years of service) and the results were as shown in the following tables:

Table 6. Statistical Description of the Sample According to the Demographic Valuables $(n=160)$

\begin{tabular}{|c|c|c|c|}
\hline \multirow{2}{*}{\multicolumn{2}{|c|}{ Characteristics and personality traits }} & \multicolumn{2}{|c|}{$\begin{array}{l}\text { Administrators and academics with } \\
\text { administrative position }\end{array}$} \\
\hline & & Frequency & Percent \\
\hline \multirow{2}{*}{ Gender } & Male & 126 & 78.8 \\
\hline & Female & 34 & 21.3 \\
\hline \multirow{4}{*}{ Age } & Less than 30 Years & 20 & 12.5 \\
\hline & $30-40$ Years & 71 & 44.4 \\
\hline & 41-50 Years & 41 & 25.6 \\
\hline & Greater than 50 Years & 28 & 17.5 \\
\hline \multirow{5}{*}{ University } & Al-Azhar & 41 & 25.6 \\
\hline & Islamic & 48 & 30.0 \\
\hline & Al-Aqsa & 44 & 27.5 \\
\hline & Palestine & 20 & 12.5 \\
\hline & Gaza & 7 & 4.4 \\
\hline \multirow{4}{*}{ Education } & Diploma & 14 & 8.8 \\
\hline & Bachelor & 78 & 48.8 \\
\hline & Master & 44 & 27.5 \\
\hline & $\mathrm{PhD}$ & 24 & 15.0 \\
\hline \multirow{7}{*}{ Managerial Class } & Associate Dean & 6 & 3.8 \\
\hline & H.Acad & 16 & 10.0 \\
\hline & Coordinator & 14 & 8.8 \\
\hline & Director & 54 & 33.8 \\
\hline & Acting Director & 7 & 4.4 \\
\hline & Assistant Director & 20 & 12.5 \\
\hline & H.Admin & 43 & 26.9 \\
\hline \multirow{5}{*}{ Years of service } & Less than 3 Years & 9 & 5.6 \\
\hline & 3-9 Years & 34 & 21.3 \\
\hline & 10-14 Years & 55 & 34.4 \\
\hline & 15-19 Years & 43 & 26.9 \\
\hline & Greater than 20 Years & 19 & 11.9 \\
\hline
\end{tabular}

The previous table shows that $78.8 \%$ of the sample is males, while the remaining $21.2 \%$ is the females. The researchers attribute the rise in the number of males over females between the university staff that the Palestinian labor market is the masculine market primarily; where jobs tend to favor male, and this was confirmed by the results of the Palestinian Central Bureau of Statistics to the low percentage of women in the labor market in its annual report entitled: women's and men's statistics in Palestine: issues and statistics, that the participation of men in the labor force increased by more than four times the participation of women during the period 2001 - 2010 (Palestinian Statistic Center, 2011).

$12.5 \%$ of the sample aged less than 30 years, $44.4 \%$ in age from 30 to less than 40 years, $25.6 \%$ aged from 40 to less than 50 years, while $17.5 \%$ of respondents over the age of 50 years. The researchers attribute this result to the Palestinian universities in the orientation to take advantage of the young energetic persons in the Palestinian society, 
which carries with it the ability for development, the ability to receive training, and refinement in various fields.

$25.68 \%$ of the sample is employees of the Al-Azhar University, $30.0 \%$ are employed at the Islamic University, $27.5 \%$ are employed in the Al-Aqsa University, $12.5 \%$ are employees in the University of Palestine, and $4.4 \%$ are employed in Gaza University. That reflects the reality of the size of Palestinian universities through the employees in these universities.

$8.8 \%$ of the sample has a diploma, $48.8 \%$ has a Bachelor's degree, $27.5 \%$ has Master's degree, while $15.0 \%$ has doctoral degree and this is a reality that the Palestinian universities seek to attract and appoint people with high degrees which are reflected on university scientific excellence.

$3.8 \%$ of the study sample is of class (deputy or assistant) Dean, $10.0 \%$ is the heads of academic departments, $8.8 \%$ has name of coordinator, $33.8 \%$ are working under the name of director, $4.4 \%$ under the named acting Director, $12.5 \%$ are carrying the name of assistant director, while the name of the head of the administrative department by $26.9 \%$. The researchers attribute this increase in managers and department heads relative to the large administrative burden, in addition to the administrative work is an important pillar of the quality of the output of universities where this result agreed with the study of (Harb, 2011) in terms of the distribution of administrative terminology.

$5.6 \%$ of the sample has at least 3 years of practical experience, $21.3 \%$ is ranging from 3 to 9 years of practical experience, $34.4 \%$ is ranging from 10 to 14 years of practical experience, $26.9 \%$ is ranging from 15-19 years of practical experience, and $11.9 \%$ has more than 20 years of practical experience. The researchers attribute the low percentage of the category of less than 3 years of experience in the slow process of recruitment and absorbing new employees.

\section{Second- analysis of the paragraphs of the questionnaire}

\section{Normal data distribution test:}

Kolmogorov-Smirnov Test was used to examine the extent of matching the data to the normal distribution, and the results are as shown in Table (7).

Table 7. The Normal Data Distribution Test Results (Kolmogorov-Smirnov Test)

\begin{tabular}{|c|c|c|c|c|}
\hline \multicolumn{1}{|c|}{ Pivot } & Mean & St. Dev. & K-S & Sig. \\
\hline Internal Environment & 7.0359 & 1.40804 & 1.848 & .002 \\
\hline Info. \& Comm. & 6.8219 & 1.52994 & 1.772 & .004 \\
\hline Average All & 6.9289 & 1.34998 & 1.586 & 0.013 \\
\hline
\end{tabular}

Kolmogorov-Smirnov Test results indicate that each of the axis of the internal control environment and the axis of information and communication, and the total score for the whole questionnaire does not follow the normal distribution. It means that non-parametric tests will be used for in analyzing the results later.

\section{The arithmetic mean test of each paragraph:}

The researchers tested the paragraphs of the study using the (t) test to see if the average degree of response to the point of neutrality (5.5) which corresponds (neutral) option in the decimal gradient. Depending on the (Sig.) value for each paragraph of the questionnaire, If it is greater than 0.05 according to the results of the (SPSS) program, it would be in this case the average views of respondents about the phenomenon under 
study does not differ materially from neutral, but if less than 0.05 , the average views of respondents are fundamentally different from the degree of neutrality.

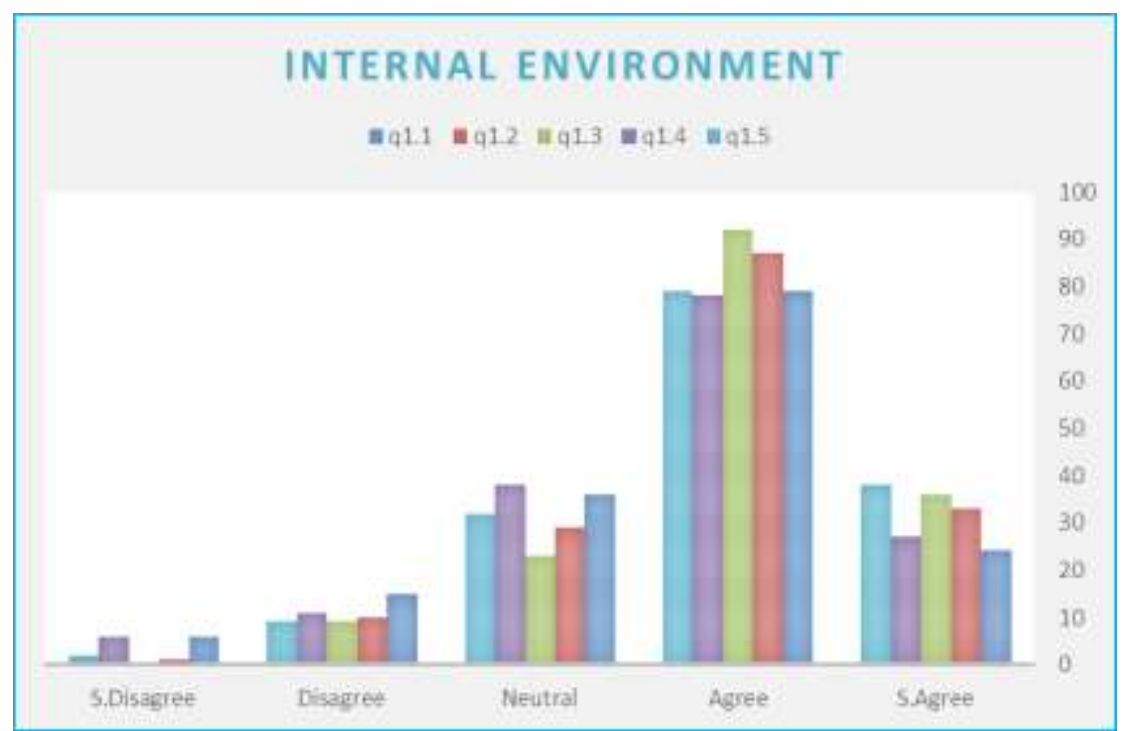

Figure 1. Iterations Answers to the First Axis (the Internal Control Environment)

Source: Prepared by researchers based on statistical data

Table 8. Tested the Arithmetic Mean of the Axis of the Internal Control Environment

\begin{tabular}{|l|c|c|c|c|c|}
\hline \multicolumn{7}{|c|}{ Test Value = 5.5 } & Maragraph & Mean & St. D. & t-value & Sig. & Order \\
\hline $\begin{array}{l}\text { Internal control system provides a description and } \\
\text { functionally defines the powers, duties, the degree of } \\
\text { knowledge, and skill to perform the work efficiently } \\
\text { and effectively in the university }\end{array}$ & 6.66 & 1.923 & 7.648 & .000 & 5 \\
\hline $\begin{array}{l}\text { Internal control check compliance with laws, } \\
\text { regulations, instructions, policies and regulations that } \\
\text { encourage employees at the university to adhere to } \\
\text { moral values in the performance of the tasks assigned } \\
\text { to them. }\end{array}$ & 7.22 & 1.612 & 13.484 & .000 & 3 \\
\hline $\begin{array}{l}\text { Internal controls contribute to the commitment that } \\
\text { each employee works under the direct supervision } \\
\text { responsibly. }\end{array}$ & 7.44 & 1.524 & 16.129 & .000 & 1 \\
\hline $\begin{array}{l}\text { University demonstrates its commitment to attract, } \\
\text { develop distinctive and qualifying elements in line } \\
\text { with targets. }\end{array}$ & 6.82 & 1.801 & 9.262 & .000 & 4 \\
\hline $\begin{array}{l}\text { Impose strict and deterrent penalties by the } \\
\text { management responsible for the university when the } \\
\text { discovery of irregularities indicates manipulation of } \\
\text { business performance. }\end{array}$ & 7.28 & 1.657 & 13.601 & .000 & 2 \\
\hline
\end{tabular}

The significance (Sig.) indicates that all average values of the paragraphs differ substantially from the value of neutrality (5.5) in favor of approval and strong approval. 


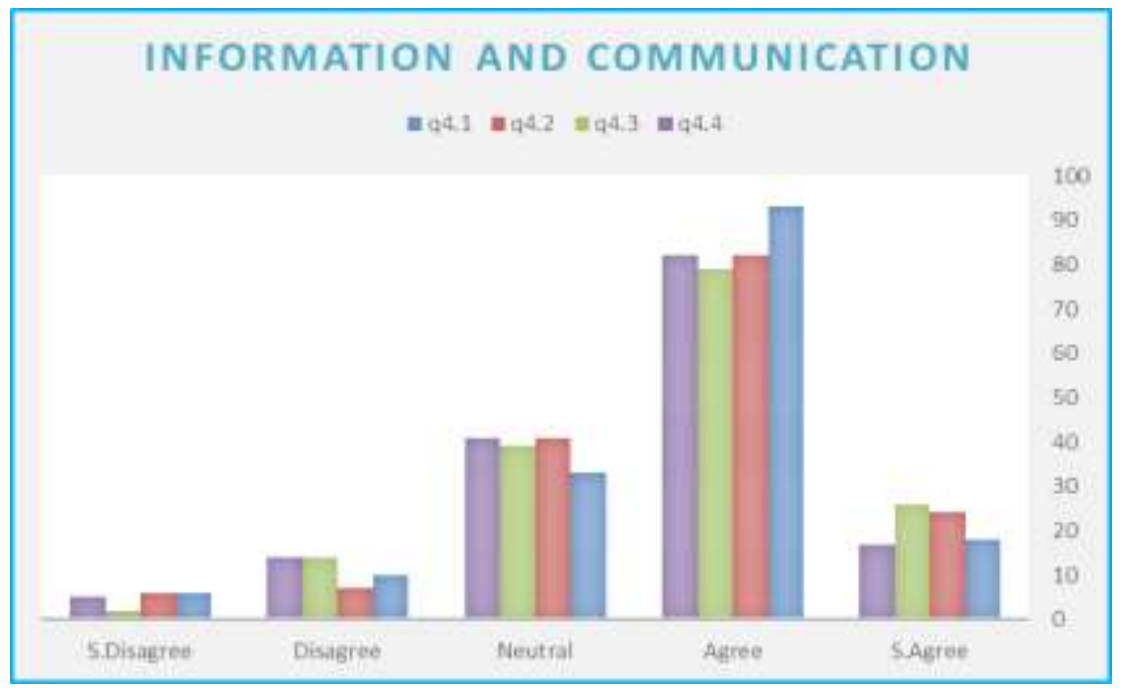

Figure 2. Answers Occurrences of the Second Axis (Information and Communication)

\section{Table 9. The Arithmetic Mean Test of the Axis of Information and Communication}

\begin{tabular}{|l|c|c|c|c|c|}
\hline \multicolumn{7}{|c|}{ Test Value = 5.5 } & Maragraph & St. D. & t-value & Sig. & Order \\
\hline $\begin{array}{l}\text { Pnternal controls provide information to } \\
\text { individuals in time to enable them to } \\
\text { pursue their responsibilities efficiently } \\
\text { and effectively. }\end{array}$ & 6.82 & 1.700 & 9.810 & .000 & 3 \\
\hline $\begin{array}{l}\text { Internal control provides efficient and } \\
\text { effective communication channels for the } \\
\text { process of transferring that data and } \\
\text { information }\end{array}$ & 6.95 & 1.769 & 10.368 & .000 & 1 \\
\hline $\begin{array}{l}\text { Management provides the best } \\
\text { administrative communication methods. }\end{array}$ & 6.86 & 1.665 & 10.349 & .000 & 2 \\
\hline $\begin{array}{l}\text { Internal control provides administrative } \\
\text { information for decision making }\end{array}$ & 6.67 & 1.774 & 8.339 & .000 & 4 \\
\hline
\end{tabular}

The level of significance (Sig.) indicates that all averages of paragraphs values differ materially from the value of neutrality (5.5) in favor of approval and strong approval.

The table above shows the arithmetic mean of the paragraphs of the axis of information and communication and it demonstrates a fundamental difference for all axis paragraphs at the significant level 0.05 .

The paragraph "internal control provides efficient and effective communication channels for the process of transferring that data and information " came in the first place. The researchers attribute that administration reports are provided, in particular, on a regular basis in order to serve the work. This result agreed with the study of (Harb, 2011) where it came in the first place with relative weight of $82.6 \%$. While the paragraph "internal control provides administrative information for decision making" got the fourth place. The researchers attribute that this paragraph got in the last rank in the paragraphs of this axis is the existence of shortcomings in the administrative communications is generally within the universities and therefore this shortcoming will impact on the control process as a whole specially the communication process is a major part of everyday business, some experts estimated that it consumes between $75-95 \%$ of staff time (Al- 
Masri, 2015). While this result differ with the study of (Harb, 2011) about the appropriate information to the requirements of work; where this paragraph got to the fourth place with relative weight of $81 \%$.

Testing study hypotheses

Testing the relationship between information and communication and internal control environment by calculating the correlation coefficient between the two variables.

Table 10. The Correlation Coefficient between the Two Variables

\begin{tabular}{|l|l|c|}
\hline & & Info. \& Communication \\
\hline Internal Environment & Pearson Correlation & $.689^{* *}$ \\
\hline & Sig. & .000 \\
\hline
\end{tabular}

The value of the correlation coefficient between the information and communication on one hand, and the internal control environment is $68.9 \%$, which is strong extrusive correlation coefficient (because it is positive) because (it is greater than 0.5), and the value of the significant correlation statistically different from zero, because (Sig.) less than the significance level of 0.05 .

Accordingly, we reject the first hypothesis of the study that says: there is no significant relationship between information and communication on one hand, and the internal control environment of another hand.

\section{Differences tests}

Table 11. Average Respondents Responses for each Axis of the Study

\begin{tabular}{|c|c|c|c|}
\hline \multicolumn{2}{|c|}{ Characteristics and personality traits } & $\begin{array}{c}\text { Internal } \\
\text { Environment }\end{array}$ & $\begin{array}{c}\text { Info. \& } \\
\text { Communication }\end{array}$ \\
\hline \multirow{2}{*}{ Gender } & Male & 6.98 & 6.75 \\
\hline & Female & 7.21 & 7.06 \\
\hline \multirow{4}{*}{ Age } & Less than 30 Years & 6.82 & 6.73 \\
\hline & $30-40$ Years & 6.98 & 6.84 \\
\hline & $41-50$ Years & 7.18 & 6.91 \\
\hline & Greater than 50 Years & 7.08 & 6.69 \\
\hline \multirow{5}{*}{ University } & Al-Azhar & 6.36 & 5.97 \\
\hline & Islamic & 7.65 & 7.28 \\
\hline & Al-Aqsa & 6.84 & 6.93 \\
\hline & Palestine & 7.28 & 7.12 \\
\hline & Gaza & 7.17 & 7.03 \\
\hline \multirow{4}{*}{ Education } & Diploma & 7.55 & 7.19 \\
\hline & Bachelor & 6.81 & 6.74 \\
\hline & Master & 6.89 & 6.43 \\
\hline & PhD & 7.70 & 7.56 \\
\hline \multirow{7}{*}{ Managerial Class } & Associate Dean & 8.45 & 7.70 \\
\hline & H.Acad & 6.90 & 6.70 \\
\hline & Coordinator & 7.73 & 7.16 \\
\hline & Director & 6.88 & 6.68 \\
\hline & Acting Director & 7.21 & 7.46 \\
\hline & Assistant Director & 7.00 & 6.82 \\
\hline & H.Admin & 6.83 & 6.69 \\
\hline
\end{tabular}




\begin{tabular}{|l|l|l|l|}
\hline \multirow{4}{*}{ Years of service } & Less than 3 Years & 6.88 & 6.80 \\
\cline { 2 - 4 } & 3-9 Years & 6.95 & 6.76 \\
\cline { 2 - 4 } & 10-14 Years & 7.31 & 6.99 \\
\cline { 2 - 4 } & 15-19 Years & 6.84 & 6.76 \\
\cline { 2 - 4 } & Greater than 20 Years & 6.86 & 6.56 \\
\hline
\end{tabular}

It was previously concluded that the respondents' responses are not subject to normal distribution, according to Kolmogorov Samaranov test results. Thus nonparametric tests will be applied in the test of differences.

Table 12. Testing the Difference between the Responses of the Individuals Sample Attributable to Gender (Mann-Whitney Test)

\begin{tabular}{|l|c|c|c|c|c|}
\hline \multicolumn{1}{|c|}{ Gender } & $\mathrm{N}$ & Mean Rank & Sum of Ranks & Mann-Whitney & Sig. \\
\hline Male & 126 & 78.67 & 9912.00 & 1911.00 & .334 \\
\hline Female & 34 & 87.29 & 2968.00 & & \\
\hline Total & 160 & & & & \\
\hline
\end{tabular}

Since the value (Sig.) is greater than the level of significance, we accept the null hypothesis (Ho) and that means there is no substantial difference between the responses of male and female.

\section{Table 13. Testing for Differences between the Responses of the Members Sample Attributable to Age (Kruskal-Wallis Test)}

\begin{tabular}{|c|c|c|c|c|c|}
\hline \multicolumn{1}{|c|}{ Age } & $\mathrm{N}$ & Mean Rank & Chi $^{2}$ & df & Sig. \\
\hline$<30$ Years & 20 & 75.18 & .746 & 3 & .862 \\
\hline 30-40 Years & 71 & 78.76 & & & \\
\hline 41-50 Years & 41 & 83.17 & & & \\
\hline$>50$ Years & 28 & 84.80 & & & \\
\hline Total & 160 & & & & \\
\hline
\end{tabular}

Since the value (Sig.) is greater than the level of significance, we accept the null hypothesis (Ho) and that means there is no substantial difference between the responses of the respondents attributed to the variable age.

Table 14. Testing for Differences between the Responses of the Members Sample Attributable to the University (Kruskal-Wallis Test)

\begin{tabular}{|l|c|c|c|c|c|}
\hline \multicolumn{1}{|c|}{ University } & $\mathrm{N}$ & Mean Rank & $\mathrm{Chi}^{2}$ & df & Sig. \\
\hline Al-Azhar & 41 & 61.85 & 19.601 & 4 & .001 \\
\hline Islamic & 48 & 101.09 & & & \\
\hline Al-Aqsa & 44 & 69.97 & & & \\
\hline Palestine & 20 & 91.15 & & & \\
\hline Gaza & 7 & 84.29 & & & \\
\hline Total & 160 & & & & \\
\hline
\end{tabular}

Since the value (Sig.) is less than the significance level, we reject the null hypothesis (Ho) and that means that there is a fundamental difference between the responses of the respondents attributed to the university variable. 
Table 15. Testing for Differences between the Responses of the Members Sample Attributable to the Educational Qualification (Kruskal-Wallis Test)

\begin{tabular}{|l|c|c|c|c|c|}
\hline \multicolumn{1}{|c|}{ Education } & $\mathrm{N}$ & Mean Rank & $\mathrm{Chi}^{2}$ & df & Sig. \\
\hline Diploma & 14 & 98.57 & 9.013 & 3 & .029 \\
\hline Bachelor & 78 & 74.65 & & & \\
\hline Master & 44 & 73.93 & & & \\
\hline PhD & 24 & 101.02 & & & \\
\hline Total & 160 & & & & \\
\hline
\end{tabular}

Since the value (Sig.) is less than the significance level, we reject the null hypothesis (Ho) and that means that there is a fundamental difference between the responses of the respondents attributed to the Qualification variable.

Table 16. Testing for Differences between the Responses of the Members Sample Attributable Administrative Level (Kruskal-Wallis Test)

\begin{tabular}{|c|c|c|c|c|c|}
\hline Managerial Class & $\mathrm{N}$ & Mean Rank & $\mathrm{Chi}^{2}$ & df & Sig. \\
\hline Associate Dean & 6 & 125.50 & 13.287 & 6 & .039 \\
\hline H.Acad & 16 & 75.25 & & & \\
\hline Coordinator & 14 & 108.46 & & & \\
\hline Director & 54 & 79.22 & & & \\
\hline Acting Director & 7 & 84.21 & & & \\
\hline Assistant Director & 20 & 74.03 & & & \\
\hline H.Admin & 43 & 71.08 & & & \\
\hline Total & 160 & & & & \\
\hline
\end{tabular}

Since the value (Sig.) is less than the significance level, we reject the null hypothesis (Ho) and that means that there is a fundamental difference between the responses of the respondents attributed to the administrative level variable.

Table 17. Testing for Differences between the Responses of the Members Sample Attributable to Years of Service (Kruskal-Wallis Test)

\begin{tabular}{|l|c|c|c|c|c|}
\hline \multicolumn{1}{|c|}{ Years of service } & $\mathrm{N}$ & Mean Rank & $\mathrm{Chi}^{2}$ & $\mathrm{df}$ & Sig. \\
\hline$<3$ Years & 9 & 69.00 & 6.278 & 4 & .179 \\
\hline 3-9 Years & 34 & 78.72 & & & \\
\hline 10-14 Years & 55 & 91.88 & & & \\
\hline 15-19 Years & 43 & 69.73 & & & \\
\hline$>=20$ & 19 & 80.55 & & & \\
\hline \multicolumn{1}{|c|}{ Total } & 160 & & & & \\
\hline
\end{tabular}

Since the value (Sig.) is greater than the level of significance, we accept the null hypothesis (Ho) and that means there is no substantial difference between the responses of the respondents attributed to the variable of years of service.

\section{Study Results}

- The existence of shortcomings in the administrative communication in general within the universities and therefore this shortcoming will reflect on the entire regulatory process especially the communication process which represents a significant part of everyday business 
- There were no significant relationship between information and communication from one side, and the internal control environment on the other side.

- The absence of a fundamental difference between the responses of the respondents attributed to the variable (gender, age, and years of service).

- The existence of a fundamental difference between the responses of the respondents attributed to the variable (university, educational qualification, the administrative level).

\section{Recommendations}

Based on the results reached by the study, the following recommendations are made:

- The Importance of updated systems and instructions for control periodically and parallel with the wheel of technology and scientific progress.

- Emphasis on administrative leaders to be a positive role model and set an example for employees in all business functions.

- Benefit from regional and international experiences in the application of control standards commensurate with the administrative system of the institution.

- The need to hold training courses for those working in universities and spread awareness of the importance of the control process and its benefits.

\section{References}

[1] Abbas, A. (2009). Basics of management science. Jordan: Dar soft for publication and distribution, and printing.

[2] Abu Amuna, Y. M., Al Shobaki, M. J., Abu Naser, S. S., \& Badwan J. J. (2017). Understanding Critical Variables For Customer Relationship Management In Higher Education Institution From Employee Perspective. International Journal of Information Technology and Electrical Engineering 6(1) $10-16$.

[3] Abu-Rahma, A. M. (2012). Develop the administrative communication in schools and periodic relief agency in Gaza governorates using Reengineering style. Master thesis, the Islamic University, Gaza, Palestine.

[4] Abu-Salmiya, I. A. (2012). "Practice of administrative communication degree at the UNRWA Gaza governorate schools managers and ways to activate it. Master thesis, the Islamic University, Gaza, Palestine.

[5] Al Shobaki, M. J., \& Naser, S. S. A. (2016). Decision support systems and its role in developing the universities strategic management: Islamic university in Gaza as a case study. International Journal of Advanced Research and Development, 1,10, 33-47.

[6] Al Shobaki, M. J., \& Naser, S. S. A. (2016). Performance development and its relationship to demographic variables among users of computerized management information systems in Gaza electricity Distribution Company. International Journal of Humanities and Social Science Research, 2,10, 21-30.

[7] Al Shobaki, M. J., \& Naser, S. S. A. (2016). The Dimensions of Organizational Excellence in the Palestinian Higher Education Institutions From The Perspective Of The Students. Global Journal Of Multidisciplinary Studies, 5, 11, 66-100.

[8] Al Shobaki, M. J., \& Naser, S. S. A. (2016). The reality of modern methods applied in process of performance assessments of employees in the municipalities in Gaza Strip. International Journal of Advanced Scientific Research, 1,7, 14-23.

[9] Al Shobaki, M. J., Amuna, Y. M. A., \& Naser, S. S. A. (2016). The impact of top management support for strategic planning on crisis management: Case study on UNRWA-Gaza Strip. International Journal of Academic Research and Development, 1, 10, 20-25.

[10] Al Shobaki, M. J., Amuna, Y. M. A., \& Naser, S. S. A. (2017). Strategic and Operational Planning As Approach for Crises Management Field Study on UNRWA. International Journal of Information Technology and Electrical Engineering, 5, 6, 43-47.

[11] Al-Qahtani, F. (2015). The fact of the internal administrative control sports clubs in Saudi Arabia, the southern region.

[12] Badawi, A. K. (2011). The impact of the internal control structure of the system according to the COSO framework to achieve the control objectives. 
[13] COBIT, (2013). Control Objectives for Information and Related Tec. 2013. COBIT 5: Enabling Information Overview and Frequently Asked Questions. ISACA, 1.

[14] Dahmash, N. \& Abu zer A. (2005). Controls and internal audit in the IT environment. Jordan: International Fifth International Conference of the Faculty of Economics and Administrative Sciences University Siouan.

[15] Duh, R., Kuo-Tay C., Ruey-Ching L., \& Li-Chun K. (2010). Do Internal Control Improve Operating Efficiency of Universities?, Taiwan.

[16] Harb, N. M. (2011). The fact of administrative transparency requirements applied in Palestinian universities in the Gaza Strip.

[17] Naser, S. S. A., \& Al Shobaki, M. J. (2016). Computerized Management Information Systems Resources and their Relationship to the Development of Performance in the Electricity Distribution Company in Gaza. European Academic Research, 9, 8, 6969-7002.

[18] Naser, S. S. A., \& Shobaki, M. J. A. (2016). Enhancing the use of Decision Support Systems for Reengineering of Operations and Business-Applied Study on the Palestinian Universities. Journal of Multidisciplinary Engineering Science Studies (JMESS), 2, 5, 505-512.

[19] Naser, S. S. A., \& Shobaki, M. J. A. (2016). Requirements of using Decision Support Systems as an Entry Point for Operations of Re-engineering in the Universities (Applied study on the Palestinian universities in Gaza Strip). World Wide Journal of Multidisciplinary Research and Development, 2, 4, $32-40$.

[20] Naser, S. S. A., \& Shobaki, M. J. A. (2016). The Impact of Management Requirements and Operations of Computerized Management Information Systems to Improve Performance (Practical Study on the employees of the company of Gaza Electricity Distribution). In First Scientific Conference for Community Development, 5-6 November, 2016 (pp. 1-28). Al-Azhar University of Gaza, Palestine.

[21] Naser, S. S. A., Al Shobaki, M. J., \& Amuna, Y. M. A. (2016). Knowledge Management Maturity in Universities and its Impact on Performance Excellence" Comparative study". Journal of Scientific and Engineering Research, 3, 4, 4-14.

[22] Naser, S. S. A., Al Shobaki, M. J., \& Amuna, Y. M. A. (2016). Measuring knowledge management maturity at HEI to enhance performance-an empirical study at Al-Azhar University in Palestine. International Journal of Commerce and Management Research, 2, 5, 55-62.

[23] Naser, S. S. A., Shobaki, M. J. A., \& Amuna, Y. M. A. (2016). Promoting Knowledge Management Components in the Palestinian Higher Education Institutions - A Comparative Study. International Letters of Social and Humanistic Sciences, 73, 42-53.

[24] Tabash, M. I. (2008). The role of systems and techniques administrative communication in the service of decision-making: Application on the Ministry of Education in the Gaza Strip. Master thesis- not published. Gaza: College of Business Administration, Islamic University, Gaza, Palestine.

[25] Yassin, G., \& Al Zoghbi, Z. (2002). Assessing the accounting programs in Jordan and Iraq. Journal of the Faculty of Management and Economics. 